PRACE GEOGRAFICZNE

zeszyt $156,2019,35-53$

doi: 10.4467/20833113PG.19.002.10306

Instytut Geografii i Gospodarki Przestrzennej UJ

Wydawnictwo Uniwersytetu Jagiellońskiego

\title{
WPEYW MISTRZOSTW ŚWIATA W PIŁCE NOŻNEJ 2018 NA WIZERUNEK TURYSTYCZNY OBWODU KALININGRADZKIEGO
}

\author{
Julia Dunaj, Dominika Studzińska
}

\section{Impact of the 2018 FIFA World Cup on the tourist image of the Kaliningrad Oblast}

Abstract: Many countries and cities seek the organization of great sports events because of its impact on the economy and society of the hosting country/region. In this article, we seek to answer the question whether the FIFA World Cup, which took place in 2018 in Russia, influenced a change in the tourist image of the Kaliningrad Oblast. The enclave is not a popular tourist destination; therefore the organization of the World Cup in Russia, including Kaliningrad, was an opportunity for the region. However, a question remains as to whether Kaliningrad used this chance appropriately. For this purpose, a survey was conducted among tourists who visited Kaliningrad during the 2018 World Cup.

Keywords: mega-events, tourism, FIFA World Cup, Kaliningrad Oblast

Zarys treści: Wiele państw i miast zabiega o organizację wielkich wydarzeń sportowych, bowiem badania potwierdzają, że przynoszą one szereg korzyści finansowych oraz poprawiają wizerunek regionów, w których odbywają się wydarzenia sportowe. Celem niniejszego artykułu jest próba odpowiedzi na pytanie, czy Mistrzostwa Świata w Piłce Nożnej (MŚ 2018), które odbyły się w 2018 r. w Rosji wpłynęły na zmianę wizerunku turystycznego Obwodu Kaliningradzkiego. Enklawa nie stanowi popularnej destynacji turystycznej, dlatego organizacja MŚ 2018 w Rosji stanowiła szansę dla regionu. W artykule autorki podejmą próbę wykazania, że izolacja enklawy w wyniku funkcjonowania nieprzepuszczalnej i silnie sformalizowanej granicy wpływa na negatywny obraz enklawy, który ulega zmianie po odwiedzeniu regionu. W tym 
celu zostało przeprowadzone badanie ankietowe z turystami, którzy odwiedzili Kaliningrad w trakcie MŚ 2018.

Stowa kluczowe: wielkie imprezy sportowe, turystyka, Mistrzostwa Świata w Piłce Nożnej, Obwód Kaliningradzki

\section{Wprowadzenie}

Pozytywny wizerunek destynacji turystycznej jest kluczem do jej rozwoju. Jego kształtowanie jest procesem długotrwałym i zależy od cech turysty, charakterystyki fizycznej i społeczno-ekonomicznej obszaru, jak również od działań podmiotów trzecich (Dudek-Mańkowska, Wawrzyszak 2017). Ważnym czynnikiem decydującym o powstaniu wizerunku turystycznego są wrażenia i doświadczenia osób odwiedzających miejsce (Łuczak 2010). Ponadto znaczący wpływ na wykreowanie obrazu turystycznego mają przekazy marketingowe oraz informacje pochodzące z mediów (Dudek-Mańkowska, Wawrzyszak 2017).

W dużej mierze turystyczny wizerunek miejsca zależy od jego atrakcyjności turystycznej. Jak podkreślają Rapacz i Jaremen (2011), atrakcyjność turystyczna to zespół czynników, które wpływają na rozwój turystyki w określonych regionach. Atrakcyjność turystyczna danego regionu zależy przede wszystkim od bogactwa środowiska przyrodniczego i kulturowego (Potocka 2009). Jak jednak zaważa Stasiak (2016), wraz ze zmianą paradygmatu turystyki coraz większe znaczenie dla turystów mają nowe formy turystyki, odkrywanie nowych przestrzeni turystycznych oraz wykorzystanie nowych technologii.

Turystyczny wizerunek miejsca nie jest stały i podlega nieustannym zmianom. Jak podają Dudek-Mańkowska i Wawrzyszak (2017), „,wizerunek destynacji turystycznej jest wyjątkowo wrażliwy na występowanie kryzysów, co wiązać można zarówno z ograniczoną liczbą promowanych wyróżników tych miejsc (wizerunek ograniczony), jak i dużym zainteresowaniem sytuacją mediów i opinii publicznej zdarzeniami w znanych miejscowościach”. W celu poprawy wizerunku turystycznego podejmowane są odpowiednie działania. Jednym z nich jest organizacja wielkich wydarzeń sportowych. Mistrzostwa Świata w Piłce Nożnej uważane są za jedno z ważniejszych wydarzeń rozwijających turystykę (Pappas 2014). Zgodnie z aktualnymi trendami w turystyce odwiedzający miasta są coraz częściej zainteresowani rozrywką i sportem, a nie jedynie zwiedzaniem (Kowalczyk 2005). Dlatego duże wydarzenia sportowe stanowią istotny element produktu turystycznego miast (Malchrowicz-Mośko i in. 2016). Pozwalają one na wykreowanie nowego wizerunku turystycznego.

W 2018 r. w ramach Mistrzostw Świata w Piłce Nożnej w Rosji (MŚ 2018) odbyły się w Kaliningradzie cztery mecze. W niniejszym artykule autorki dokonają analizy wpływu MŚ 2018 na wykreowanie nowego wizerunku turystycznego Obwodu 
Kaliningradzkiego. W tym celu zbadano opinię turystów na temat potencjalnego wpływu analizowanego wydarzenia na rynek turystyczny enklawy. Autorki zwróciły szczególną uwagę na zmianę postrzegania obwodu po przyjeździe do Kaliningradu. Jak wynika z badań przeprowadzonych przez Centrum Badania Opinii Społecznej (2016), od 2012 r. stopniowo wzrasta wśród Polaków niechęć do Rosjan. Negatywny stosunek do Rosjan wykazują także inne narodowości. Czy jest ona jednak uzasadniona? W artykule autorki podejmą próbę wykazania, że negatywne stereotypy o Obwodzie Kaliningradzkim są pochodną izolacji enklawy. W opinii autorek wyniki tego badania należy potraktować jako wstępne, bowiem w celu ocenienia korzyści i strat wynikających z organizacji tego wydarzenia niezbędne jest przeprowadzenie szeregu analiz w późniejszym czasie. Efekty realizacji wielkich wydarzeń sportowych są najczęściej zauważalne w dłuższej perspektywie.

\section{Wielkie wydarzenia sportowe i ich konsekwencje}

Tematyka wielkich wydarzeń sportowych jest podejmowana przez naukowców od lat 80. XX w. (Fourie, Santana-Gallego 2011). Literatura zagraniczna poświęcona temu zagadnieniu jest obszerna (m.in. Zhou, Ap 2009; Fourie, Santana-Gallego 2011; Lorde i in. 2011; Pappas 2014; Caiazza, Audretsch 2015; Chen, Tian 2015; Knott i in. 2015). Wynika to zarówno ze skali imprezy, jak również z jej długotrwałego i istotnego wpływu na miasta-gospodarzy (Chen, Tian 2015). Ta niezwykle ważna tematyka zyskała zainteresowanie polskich naukowców wraz z organizacją Mistrzostw Europy w Piłce Nożnej, które odbyły się na terenie Polski i Ukrainy w 2012 r. (np. Kozak 2010b; Borzyszkowski 2012; Toman, Borzyszkowski 2012; Marczak 2014).

Wielkie wydarzenia sportowe definiowane są jako wyjątkowe eventy o zasięgu międzynarodowym, odbywające się w konkretnym mieście (Caiazza, Audretsch 2015). Ich niezwyczajność wynika z jednorazowego charakteru (ang. one-time event) (Jago, Shaw 1998). Jak podkreśla Roche (2006), wielkie wydarzenie sportowe to krótkoterminowe zdarzenie o długofalowych skutkach dla miast-organizatorów. Cechuje je z reguły wzorowa organizacja (Marczak 2014). „Dla wydarzeń sportowych znamienny jest charakter przeżycia, wysoki stopień nacechowania emocjonalnego, wyjątkowość i autentyczność" (Malchrowicz-Mośko 2015; Malchrowicz-Mośko i in. 2016). Tym samym idealnie wpisują się $\mathrm{w}$ nowy paradygmat turystyki oparty na motywach podróżowania 3xE (edukacja, ekscytacja, rozrywka) (Kozak 2010a).

Organizacja wielkiego wydarzenia sportowego niesie ze sobą pozytywne i negatywne konsekwencje: społeczno-kulturowe, gospodarcze, marketingowe, ekologiczne i przestrzenne. Podstawą rywalizacji ośrodków miejskich o organizację wielkiego wydarzenia sportowego są korzyści ekonomiczne. Do najważniejszych z nich należą: wzrost przychodów z turystyki i handlu, spadek bezrobocia, poprawa 
wyposażenia w infrastrukturę noclegowo-gastronomiczną, komunikacyjną i towarzyszącą (głównie sportową). Dobrego przykładu w tym zakresie dostarczają Igrzyska Olimpijskie w Barcelonie, które odbyły się w 1992 r. Są one uznawane za wzór organizacji i korzyści społeczno-gospodarczych (Borzyszkowski 2012). Warto również przytoczyć przykład Portugalii, gdzie po Mistrzostwach Europy w Piłce Nożnej w 2004 r. odnotowano wzrost liczby noclegów udzielonych turystom (z 33,9 mln w 2004 r. do 39,2 mln w 2008 r.) (Marczak 2014).

Organizacja wielkich wydarzeń sportowych może przyczyniać się także do negatywnych efektów ekonomicznych. Jednym z nich może być kosztowne utrzymanie tzw. białych słoni, czyli obiektów sportowych wybudowanych w celu organizacji konkretnego wydarzenia sportowego (Malchrowicz-Mośko 2015). Dobrego przykładu w tym względzie dostarczają stadiony powstałe na Mistrzostwa Europy w Piłce Nożnej w Portugalii (Kozak 2010b). Z kolei wzrost zatrudnienia na okres wydarzenia może być związany wyłącznie z tymczasowym zatrudnieniem do obsługi turystów. Ponadto często pracę tę podejmują pracownicy z innych krajów, ze względu na tańszą siłę roboczą (Malchrowicz-Mośko 2015). Kozak (2010b) zauważa, że turystyka sportowa związana z organizacją wielkich wydarzeń sportowych może zahamować rozwój innych form turystyki, np. w wyniku wzrostu cen na okres imprezy oraz dużego zatłoczenia miasta.

Wielkie wydarzenia sportowe mogą mieć pozytywny wpływ na społeczności miasta/kraju-organizatora. Przykładami są wzrost poczucia dumy narodowej oraz integracja społeczności lokalnej (Malchrowicz-Mośko 2015). Miasta-gospodarze muszą być jednak świadome potencjalnych kosztów społecznych takich jak: gentryfikacja i wzrost nierówności społecznych (Maiello, Pasquinelli 2015), utrudnienia w normalnym funkcjonowaniu mieszkańców, m.in. zatłoczenie miasta lub niewłaściwe zachowania kibiców (Malchrowicz-Mośko 2015). Zdając sobie sprawę z negatywnych skutków społecznych, takie miasta jak Oslo, Kraków, Sztokholm i Lwów zrezygnowały z rywalizacji o organizację zimowej olimpiady w 2022 r. (Maiello, Pasquinelli 2015). Potwierdza to, że potencjalni gospodarze coraz bardziej świadomie podchodzą do organizacji wielkich wydarzeń sportowych, uwzględniając wolę mieszkańców.

Ekologiczne skutki wielkich wydarzeń sportowych są zdecydowanie negatywne. Do korzyści zaliczyć można wyłącznie wdrażanie programów zrównoważonego rozwoju oraz wzrost świadomości społecznej, ale wymaga to propagowania tej idei przez organizatorów igrzysk. Zdecydowanie wydarzenia tego typu związane są ze wzrostem hałasu, produkcji śmieci i przekształceniem terenów przyrodniczych pod budowę obiektów sportowych (Malchrowicz-Mośko 2015).

Miasta nie rezygnują jednak z rywalizacji o miano gospodarza wielkiego wydarzenia sportowego, bowiem promocja i możliwość zmiany wizerunku stanowią dla władz samorządowych ważny powód jego organizacji (Knott i in. 2015). Znaczenie 
mediów w promowaniu tego typu wydarzenia wydaje się nieocenione. Globalne przekazy telewizyjne pozwalają tworzyć „światowy” wizerunek miast-gospodarzy (Short i in. za: Kozak 2010b).

\section{Specyfika Obwodu Kaliningradzkiego a turystyka}

O wyjątkowości Obwodu Kaliningradzkiego stanowi jego położenie geopolityczne i militarny charakter. Włączony po II wojnie światowej do Związku Socjalistycznych Republik Radzieckich (ZSRR) region ten stanowił jeden z najbardziej niedostępnych obszarów na terenie Europy. W 1946 r. został zaliczony do kategorii „zakazanej strefy granicznej" (Sakson 2014a). Było to efektem rozlokowania na jego terenie bazy Floty Bałtyckiej, sił lądowych i wojsk powietrznych. Port morski w Bałtijsku był jednym z największych portów wojennych w Europie (Kotowicz 2012).

Ostatecznie obwód zmienił swój charakter wraz z rozpadem ZSRR dnia 8 grudnia 1991 r. (Palmowski 2013). Zaowocowało to utworzeniem rosyjskiej „wyspy” otoczonej przez republiki bałtyckie (Sakson 2014a). Wraz z przystąpieniem Polski i Litwy do Wspólnoty Europejskiej, a następnie do strefy Schengen, Obwód Kaliningradzki stał się rosyjską eksklawą wewnątrz Unii Europejskiej (Rogoża i in. 2012). Rozszerzenie strefy Schengen znacząco osłabiło współpracę transgraniczną Obwodu Kaliningradzkiego z sąsiadami oraz utrudniło ruch transgraniczny na granicach polsko-rosyjskiej i litewsko-rosyjskiej (Palmowski 2013). To odizolowanie, $\mathrm{z}$ jednej strony od Rosji kontynentalnej wynikające z dystansu fizycznego ${ }^{1}$, z drugiej zaś od Unii Europejskiej w związku z uregulowaniami polityczno-prawnymi uniemożliwia zdynamizowanie rozwoju społeczno-gospodarczego regionu. Bezsprzeczny pozostaje fakt, że sytuacja społeczno-gospodarcza enklawy jest niezadowalająca. $Z$ analiz przeprowadzonych przez Wiśniewską i in. (2016) wynika, że kryzys gospodarczy w Rosji wzmacnia niekorzystną sytuację ekonomiczną regionu.

Bez wątpienia jedną z szans na poprawę sytuacji społeczno-gospodarczej w Obwodzie Kaliningradzkim jest rozwój turystyki. Należy jednak podkreślić, że rozwój turystyki nigdy nie był priorytetem w Rosji, choć wydaje się, że ostatnie działania rządowe pokazują zmianę w tym myśleniu (Andrades, Dimanche 2017). Obwód Kaliningradzki ma odpowiedni potencjał turystyczny, jednak podstawą poprawy atrakcyjności turystycznej enklawy jest jej odpowiednie zagospodarowanie turystyczne. Jak zauważa Wenerski (2014), przestarzały transport miejski oraz brak hoteli o średnim standardzie, a także rozpoznawalnych hoteli sieciowych utrudnia czerpanie zysków z turystyki.

\footnotetext{
${ }^{1}$ Obwód Kaliningradzki jest położony w odległości 600 km od Rosji kontynentalnej.
} 
W Obwodzie Kaliningradzkim możliwy jest rozwój różnych form turystyki, jednak wymaga to podjęcia odpowiednich działań. Na przykład rozwój turystyki wypoczynkowej jest ograniczony w wyniku zamknięcia części plaż, ze względu na wydobycie bursztynu. Z kolei turystyka morska na Zalewach Kurońskim i Wiślanym jest ograniczana przez władze rosyjskie niekorzystnymi dla turystów przepisami dotyczącymi wpływania do portów na terenie Obwodu Kaliningradzkiego (Rogoża i in. 2012).

Badania przeprowadzone przez Domaniewskiego i Studzińską (2016) wśród mieszkańców polskiej strefy przygranicznej z Rosją wykazały, że do wyjazdów do Obwodu Kaliningradzkiego zniechęcają Polaków: obawa o własne bezpieczeństwo, strach przed procedurami granicznymi oraz niestabilność polityczna enklawy. Zdaniem mieszkańców polskiej strefy przygranicznej Kaliningrad jest miastem zaniedbanym, które nie może zaoferować polskim turystom odpowiedniego poziomu usług w relacji do cen za ich świadczenie. Brak odpowiednich kampanii reklamowych, stron internetowych oraz informacji o atrakcjach turystycznych w języku angielskim również zniechęcają zagranicznych turystów (Andrades, Dimanche 2017). Tym samym region odwiedzają głównie Rosjanie, co znajduje potwierdzenie w badaniach Kropinovej (2015), która podaje, że w 2013 r. Obwód Kaliningradzki odwiedziło 475 tys. turystów, z czego 90\% stanowili turyści z Rosji kontynentalnej. Wśród turystów zagranicznych dominują Niemcy, odwiedzający region w ramach podróży sentymentalnych (Palmowski 2013). Warto podkreślić, że od 2009 r. liczba turystów odwiedzających enklawę systematycznie wzrasta, dlatego można stwierdzić, że organizacja Mistrzostw Świata w Piłce Nożnej w 2018 r. mogła stanowić przełomowy moment w rozwoju sektora turystycznego w Obwodzie Kaliningradzkim.

\section{Mistrzostwa Świata w Piłce Nożnej 2018 w Rosji}

Według danych agencji analitycznej przy rządzie Federacji Rosyjskiej popularność Rosji jako kierunku turystycznego w ostatnich latach spadła. W 2015 r. Rosję odwiedziło ok. 26,9 mln turystów zagranicznych, z kolei w 2017 r. 24,4 mln (Statista 2018). Wynika to nie tylko z niewystarczająco rozwiniętego sektora turystycznego oraz reżimu wizowego, ale również chłodnych stosunków na linii Rosja-USA oraz Rosja-Unia Europejska. Od początku 2018 r. liczba podróży turystycznych do Rosji zaczęła się stabilizować. Od stycznia do czerwca 2017 r. do Rosji przyjechało 10,95 mln turystów, w tym samym okresie w 2018 r. odnotowano 10,92 mln turystów (Raport..., 2018).

Rosja jest głównie odwiedzana przez turystów z Ukrainy, Kazachstanu, Polski, Finlandii i Chin (Rosstat 2016). Warto zwrócić uwagę, że turyści masowo odwiedzają wyłącznie Moskwę i Sankt Petersburg (Andrades, Dimanche 2017). Przeciętnemu podróżnikowi ciężko jest dotrzeć do Rosji, dlatego Rosja pozostaje w świadomości 
wielu osób krajem niebezpiecznym i tajemniczym, na którego temat istnieje wiele mitów i stereotypów.

Do momentu organizacji MŚ 2018 wiele regionów w Rosji nie było odpowiednio przygotowanych do obsługi turystów zagranicznych. Do odległych terenów, jak np. Sarańsk, docierali tylko nieliczni turyści. Obwód Kaliningradzki, pomimo jego lokalizacji w bezpośrednim sąsiedztwie krajów Unii Europejskiej nie stanowił popularnej destynacji turystycznej. Bez wątpienia wynika to z ogólnej opinii, iż Kaliningrad stanowi militarną enklawę zamkniętą dla ruchu turystycznego. Organizacja MŚ 2018 stworzyła szansę na zmianę tego poglądu. Aby zrealizować ten cel, podjęto szereg działań, które miały zaspokoić potrzeby kibiców w czasie trwania mistrzostw, ale również zachęcić turystów do odwiedzania Obwodu Kaliningradzkiego już po zakończeniu mundialu.

Stadion piłkarski Kaliningrad był najważniejszym elementem przygotowań do MŚ 2018, więc główny nacisk został położony na jego budowę i zagospodarowanie terenów w jego pobliżu (fot. 1). Na uwagę zasługuje fakt, że do ogłoszenia wyników komisji konkursowej FIFA obszar, na którym powstał stadion, był absolutnie niezagospodarowany. Plan projektu stadionu i miejsce jego budowy zmieniano wielokrotnie. Przeprowadzono szereg wstępnych prac na rzecz wzmocnienia gruntu, ponieważ ziemia na miejscu budowy stadionu była bardzo niestabilna. Istniała nawet groźba podtopień z powodu lokalizacji w bezpośrednim sąsiedztwie rzeki Pregoły. Wraz z powstaniem stadionu zlikwidowano część terenów zielonych. Wywołało to serię protestów ekologów i społeczności lokalnej. Część stadionu zlokalizowano na terenie nieruchomości prywatnej, co spotkało się ze sprzeciwem mieszkańców i powstaniem ruchów społecznych na rzecz ochrony praw właścicieli. Mimo istniejących problemów projekt stadionu w Kaliningradzie został zatwierdzony przez państwową i międzynarodową komisję. Wartość jego budowy przekroczyła szacowaną kwotę. Według danych FIFA koszt całego kompleksu wyniósł 17,7 mld rubli (ok. 1,2 mld zł). Władze miasta, świadome losu innych obiektów sportowych pozostających po wielkich imprezach sportowych, zdecydowały, że w przyszłości część konstrukcji stadionu (obecnie liczba miejsc wynosi 35 tys.) będzie zdemontowana, a pozostała będzie areną dla lokalnego klubu piłkarskiego. Planowane jest również wykorzystanie stadionu do organizacji imprez kulturalnych.

W celu zapewnienia turystom dostępu do hoteli na odpowiednim poziomie przestarzała infrastruktura została odnowiona i wzbogacona o nowe obiekty. Na przykład zostały wybudowane: Aparthotel Europa, Hotel Crystal House 5* oraz rekreacyjno-uzdrowiskowy kompleks Langendorff. Wiadomość o tym, że Kaliningrad w 2018 r. będzie gospodarzem mundialu, zachęciła niektóre światowej sławy marki hotelarskie do otwarcia swoich hoteli. Wśród nich można wymienić hotel Mercure oraz Holiday Inn. Według biura prasowego rządu Obwodu Kaliningradzkiego w trakcie trwania mundialu 224 obiekty noclegowe oferowały noclegi dla ok. 11,6 tys. osób. 
Przeprowadzone zostały prace modernizacyjne infrastruktury transportowej. Wybudowano nowe mosty i drogi. Dużym osiągnięciem był oddany do użytku nowy, międzynarodowy terminal pasażerski lotniska Chrabrowo. Ponadto w celu ułatwienia turystom pobytu w enklawie otwarto dodatkowy punkt informacji turystycznej. Oferta biur turystycznych została poszerzona o lokalne wycieczki po enklawie. Wprowadzono napisy w języku angielskim na ulicach, żeby ułatwić przemieszczanie się turystom, a także ustawiono tablice $\mathrm{z}$ informacją na temat atrakcji turystycznych w mieście. Wzrosła liczba pracowników hoteli i restauracji posługujących się językiem angielskim. W restauracjach wprowadzono menu w językach obcych. Tym samym Kaliningrad przekształcił się w międzynarodową destynację turystyczną, wyposażoną w pełną infrastrukturę niezbędną do obsługi ruchu turystycznego.

Według informacji rządu Obwodu Kaliningradzkiego liczba kibiców, którzy przekroczyli granicę lądową enklawy z paszportem kibica (Fan ID) podczas meczów 16, 22, 25 i 28 czerwca - wyniosła odpowiednio 3 891, 4 341, 1 902, 5660 osób. Według danych lotniska Chrabrowo w trakcie czterech dni meczów odprawiono na nim ponad 24 tys. pasażerów (Chrabrowo, 2018).

Na wszystkie mecze, które rozegrano w Rosji od 14 czerwca do 6 lipca 2018 r., przyszło ponad 2,66 mln osób. Średnio jeden mecz na stadionie obejrzało 45910 widzów. Cztery mecze w Kaliningradzie obejrzało łącznie 132249 widzów. Średnia frekwencja wyniosła 33062 widzów (tab. 1). Najwięcej kibiców na stadionie Kaliningrad przyszło na mecze Anglia-Belgia i Hiszpania-Maroko (33 973 widzów). Trochę mniej obejrzało mecz Serbia-Szwajcaria (33 167 widzów). Najmniejszym zainteresowaniem cieszył się mecz Chorwacja-Nigeria, na który przyszło 31136 widzów (Turystyka w Rosji, 2018). Warto podkreślić jednak fakt, że w trakcie trwania MŚ 2018 stadion w Kaliningradzie był prawie całkowicie wypełniony kibicami.

Zainteresowanie Kaliningradem w trakcie mundialu było większe, aniżeli szacowano. Potwierdza to analiza przeprowadzona przez serwis podróżniczy One'TwoTrip, w której sprawdzono częstość pojawiania się w mediach społecznościowych (Instagram, Facebook i Twitter) w okresie od 13 czerwca do 29 czerwca hasła „Kaliningrad” lub określeń, które były semantycznie powiązane z tematem MŚ 2018 (w różnych językach obcych). Przeprowadzona analiza pozwoliła stwierdzić, że Kaliningrad był jednym z popularniejszych miast do odwiedzenia podczas MŚ 2018. Zajął trzecie miejsce $(11,5 \%$ w ogólnej liczbie wskazań użytkowników mediów społecznościowych), zaraz po Moskwie i Sankt Petersburgu. Mając na uwadze masowość podróży do Sankt Petersburga i Moskwy, uplasowanie Kaliningradu na trzecim miejscu bez wątpienia daje nadzieję na rozwój turystyki w enklawie po MŚ 2018. Należy podkreślić, że tak wysoka pozycja Kaliningradu związana była prawdopodobnie z bliskością miasta względem państw Unii Europejskiej, a także z faktu, że większość zespołów rozgrywających mecze w enklawie stanowili faworyci MŚ 2018 z krajów europejskich. 


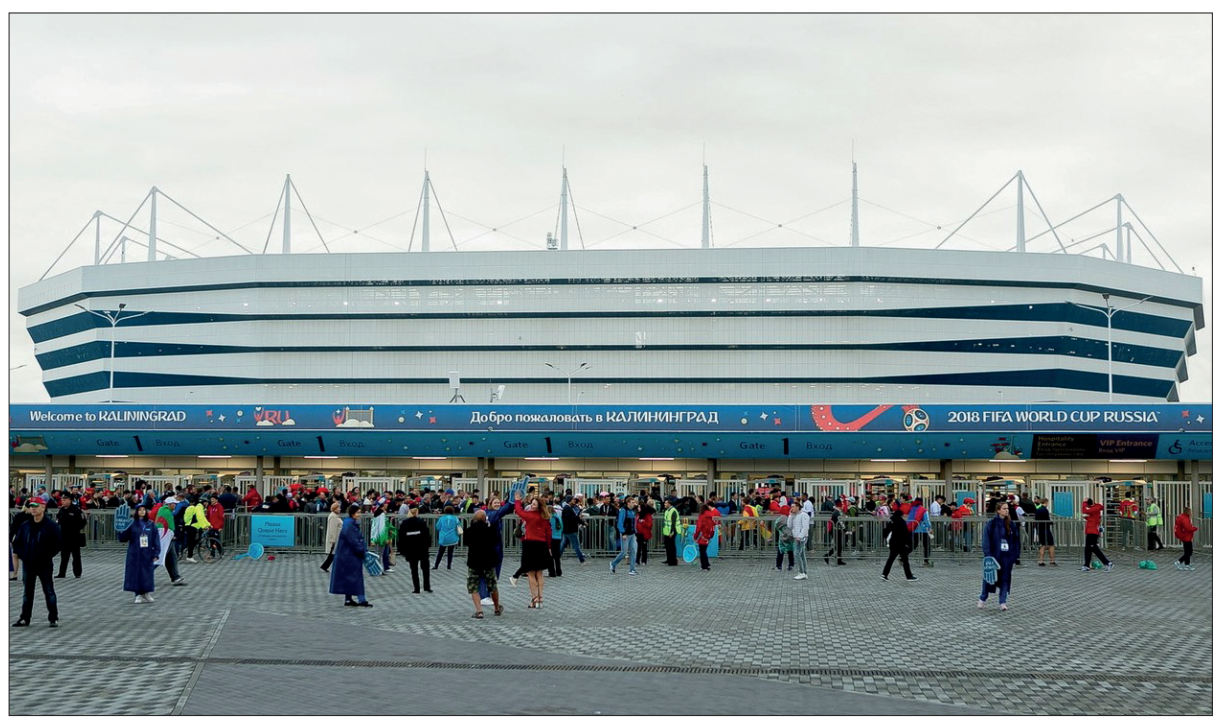

Fot. 1. Stadion piłkarski w Kaliningradzie (fot. J. Dunaj)

Photo 1. Kaliningrad football stadium (photo J. Dunaj) 
Tab. 1. Liczba kibiców na stadionach w Rosji w trakcie MŚ 2018

Table 1. Fan attendance at Russian stadiums during the 2018 World Cup

\begin{tabular}{|c|l|c|c|}
\hline $\begin{array}{c}\text { Lp. } \\
\text { No. }\end{array}$ & \multicolumn{1}{|c|}{ Miasto / City } & $\begin{array}{c}\text { Liczba kibiców } \\
\text { Total attendance }\end{array}$ & $\begin{array}{c}\text { Średnia liczba kibiców na mecz } \\
\text { Average attendance per game }\end{array}$ \\
\hline 1. & Moskwa & 767027 & 63920 \\
\hline 2. & Sankt Petersburg & 448606 & 64086 \\
\hline 3. & Soczi & 264057 & 44010 \\
\hline 4. & Niżny Nowogród & 256427 & 42738 \\
\hline 5. & Kazan & 254451 & 42408 \\
\hline 6. & Samara & 248060 & 41343 \\
\hline 7. & Rostov-na-Donu & 214197 & 42839 \\
\hline 8. & Wołgograd & 160980 & 40245 \\
\hline 9. & Czarnków & 160197 & 40049 \\
\hline 10. & Kaliningrad & 132249 & 33062 \\
\hline 11. & Jekaterynburg & 125437 & 31359 \\
\hline
\end{tabular}

Źródto: opracowanie własne na podstawie Turystyka wo Rosji, 2018.

Source: author's own elaboration based on Turystyka w Rosji, 2018.

Podsumowując, warto podkreślić, że w trakcie MŚ 2018 do Obwodu Kaliningradzkiego przyjechało dziesięć razy więcej turystów niż zazwyczaj. Według wstępnych danych, które podał szef regionalnego ministerstwa turystyki Andrej Jermak, w czasie MŚ 2018 region odwiedziło 130 tys. kibiców, czyli o 74\% więcej niż w roku ubiegłym, w tym okresie (Kaliningrad..., 2018). Tym samym Kaliningrad zyskał szansę na zwiększenie ruchu turystycznego, jednak rozwój turystyki w enklawie uzależniony jest od opinii turystów na temat regionu. Sama masowość przyjazdów w trakcie trwania MŚ 2018 nie zapewni regionowi korzyści gospodarczych w późniejszym okresie. Niezbędne do rozwoju turystyki są pozytywne opinie na temat tego regionu Rosji przekazywane przez uczestników MŚ 2018, które mogą zachęcić potencjalnych turystów do podróży do Kaliningradu.

\section{Metodyka badań}

W trakcie trwania Mistrzostw Świata w Piłce Nożnej 2018 r. przeprowadzono serię wywiadów kwestionariuszowych. Niniejsze badanie ankietowe zostało 
przeprowadzone wśród uczestników meczy odbywających się w Kaliningradzie. W trakcie badania podjęto próbę wyjaśnienia podstawowych motywów podjęcia przez kibiców podróży do Rosji, wskazania funkcjonujących w świadomości turystów stereotypów na temat Rosji i jej mieszkańców, a także uzyskanie informacji o długości pobytu i planów na spędzenie wolnego czasu w przerwach między meczami. Ponadto respondenci zostali poproszeni o: ocenę organizacji MŚ 2018, atrakcyjności turystycznej enklawy oraz poziomu infrastruktury turystycznej. Intencją autorek było zbadanie, czy przyjazd do Obwodu Kaliningradzkiego zmienił opinię kibiców na temat Rosji i Rosjan. Badanie ankietowe zostało przeprowadzone metodą bezpośrednią (PAPI) w języku angielskim, w pobliżu stadionu piłkarskiego oraz na terenie obiektów noclegowych w Kaliningradzie. Badanie zrealizowano w dniach od 1 do 29 czerwca (w dniu meczu, w przeddzień i w dzień następny). Udział w ankiecie był dobrowolny. Uzyskano próbę n=152 wśród kibiców z 28 krajów świata.

\section{Mistrzostwa Świata w Piłce Nożnej 2018 w Rosji w opinii kibiców}

Dominującą grupę uczestników MŚ 2018 stanowili mężczyźni (87\% badanych) i osoby w wieku od 18 do 45 lat ( $88 \%$ respondentów). Respondentów w wieku od 46. do 60. roku życia było $11 \%$. Z kolei $1 \%$ ankietowanych stanowiły osoby powyżej 61. roku życia. Większość badanych zadeklarowała, że ma wykształcenie wyższe (82\%) i pracuje (85\%). Z przeprowadzonych autorskich badań terenowych wynika, że największa liczba ankietowanych przyjechała z Europy (ok. 57\% badanych) oraz Afryki (22\% respondentów). Bez wątpienia przeważająca liczba kibiców z Europy wynikała z tego, że w Kaliningradzie mecze były rozgrywane głównie przez drużyny europejskie.

W strukturze kibiców europejskich dominowali turyści z Europy Północnej i Zachodniej, którzy stanowili 32\% wszystkich uczestników meczów. Wśród nich większość pochodziła z Anglii (53\%) i Belgii (18\%). Jak podała „Gazeta Wyborcza” (2018), do Obwodu Kaliningradzkiego wjechało z Polski 46 autokarów, wiozących zorganizowane grupy angielskich i belgijskich fanów piłki nożnej. Kibice z Europy Południowo-Środkowej stanowili 25\% ogółu kibiców. Wśród nich dominowali obywatele Chorwacji (42\%) i Polski (37\%). Wśród Afrykańczyków przeważali obywatele Maroka. Chociaż warto zaznaczyć, że 1/3 marokańskich respondentów podała, że przyjechali z krajów europejskich (głównie z Niemiec). Badanych z Azji, chociaż nie byli najliczniejszą grupą, cechowała różnorodność, bowiem byli to obywatele: Indonezji, Tajwanu, Chin, Indii, Pakistanu oraz Bangladeszu i Syrii.

Głównym motywem uczestnictwa w MŚ 2018 była chęć kibicowania i wspieranie państwowych drużyn piłkarskich (83\% respondentów). Zaledwie 13\% ankietowanych 
podało, że przyjechało do enklawy w celach turystycznych. Wśród odpowiedzi badanych pojawiły się również takie jak: regularne uczestnictwo w MŚ, realizacja marzenia oraz chęć zdobycia nowych doświadczeń. Na przykład Polacy podkreślali, że oprócz kibicowania i możliwości poczucia atmosfery mundialu, ważnym bodźcem zachęcającym do udziału w tym wydarzeniu była bliskość Kaliningradu. Bez wątpienia można stwierdzić, że dominującym motywem podjętej podróży do Kaliningradu była chęć udziału w meczach, jednak istotne były także imprezy towarzyszące tworzące atmosferę mundialu, jak również możliwość odwiedzania Rosji.

Większość badanych nigdy nie była w Rosji (95\%). Jak podało 34\% respondentów, nigdy nie myśleli oni o odwiedzeniu Rosji. Spośród wszystkich badanych 55\% chciało zwiedzić Rosję, ale wcześniej tego nie zrobiło. Organizacja MŚ 2018 okazała się ważnym impulsem do podjęcia decyzji o podróży do Rosji. Można stwierdzić, że liberalizacja reżimu wizowego na czas trwania MŚ 2018 i możliwość swobodnego przekraczania granicy z tzw. paszportem kibica zachęciły tych uczestników mundialu, dla których procedury wizowe stanowiły ważny czynnik zniechęcający do podróży do Rosji.

Intencją autorek było uzyskanie informacji na temat pobytu w Kaliningradzie podczas MŚ 2018. Odpowiednio $43 \%$ badanych przyjechało do Kaliningradu na dwa dni i $44 \%$ deklarowało, że przebywało w enklawie od 3 do 7 dni (ryc. 1). Około 6\% badanych zdecydowało się na dłuższy, ponad tygodniowy pobyt turystyczny w Kaliningradzie. $\mathrm{Na}$ jednodniowy przyjazd zdecydowało się ok. $7 \%$ kibiców.

W badaniach poświęconych wielkim wydarzeniom sportowym szczególną uwagę zwraca się na formę spędzania czasu między udziałem w nich. W tym celu zapytano ankietowanych o aktywność pomiędzy meczami. Respondenci mogli wskazać, czy zainteresowani byli odwiedzeniem zabytków, degustacją tradycyjnych dań lub nawiązaniem

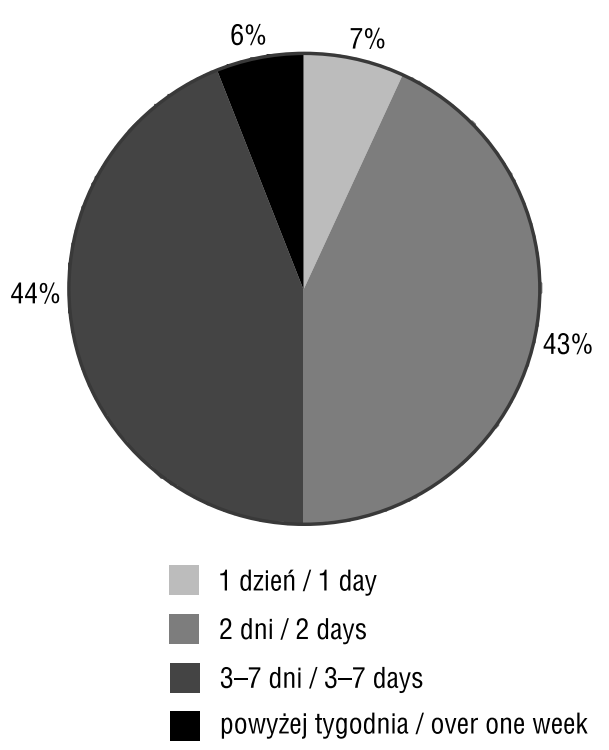

Ryc. 1. Pobyt kibiców w Kaliningradzie podczas MŚ 2018

Fig. 1. Stay of fans in Kaliningrad during the 2018 World Cup

Źródto: opracowanie własne na podstawie badań ankietowych.

Source: author's own elaboration based on the questionnaire survey. 
kontaktu z mieszkańcami. Badani mogli zaznaczyć kilka odpowiedzi lub wskazać własną. Wszystkie z powyższych opcji zaznaczyło $18 \%$ badanych. Niemniej jednak, badani podali, że w wolnym czasie głównie zwiedzali zabytki $(63 \%)$ i degustowali potrawy lokalnej kuchni 58\% (ryc. 2). Na integrację ze społecznością lokalną wskazało $48 \%$ badanych. Brak zainteresowania kulturą rosyjską wykazało $9 \%$ respondentów.

Dla rozwoju turystyki w enklawie istotne było pozytywne ocenienie przez kibiców biorących udział w MŚ 2018 przygotowanej infrastruktury noclegowej. Rozwój bazy noclegowej został doceniony przez turystów. Większość badanych (40\%) oceniło bardzo dobrze obiekty, w których nocowali. Zaledwie $3 \%$ ankietowanych podało, że baza noclegowa była zła. Dobrze oceniło infrastrukturę turystyczną 37\% badanych. Część ankietowanych (20\%) ze względu na jednodniowy pobyt turystyczny nie mogła ocenić jakości bazy noclegowej. Wśród niedogodności turyści wymieniali jedynie problemy ze znalezieniem zarezerwowanych mieszkań, odbieganiem ich stanu rzeczywistego od przedstawianego w reklamach oraz ich lokalizację w zaniedbanych częściach miasta.

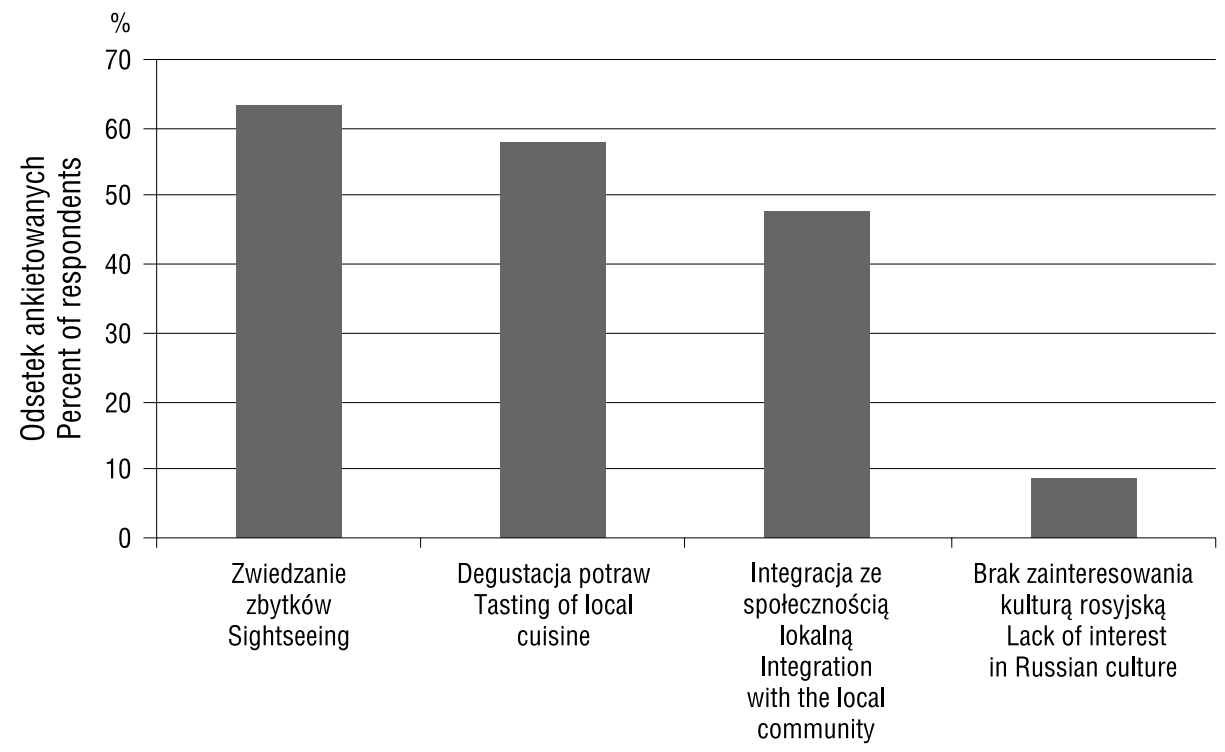

Ryc. 2. Zainteresowanie kulturą rosyjską wśród kibiców MŚ 2018

Fig. 2. Interest in Russian culture according to the fans of the 2018 World Cup

Źródto: opracowanie własne na podstawie badań ankietowych.

Source: author's own elaboration based on the questionnaire survey. 
Dużym wyzwaniem dla Kaliningradu było zapewnienie turystom dostępu do sprawnie działającej komunikacji publicznej. Spośród wszystkich badanych $20 \%$ podało, że komunikacja publiczna w Kaliningradzie jest bardzo dobra, a ok. 50\% badanych oceniło ją dobrze. Szczególnie wysoko ankietowani ocenili dostęp do bezpłatnych autobusów dowożących kibiców na stadion. Zdaniem $30 \%$ respondentów transport publiczny w Kaliningradzie jest średni.

Organizacja MŚ 2018 umożliwiła rozwój różnych form turystyki w enklawie i promocję jej atrakcyjności turystycznej. Z przeprowadzonych badań terenowych można wywnioskować, że turyści, którzy przyjechali do enklawy, zapoznali się z ofertą turystyczną tego regionu Rosji i w trakcie swojego pobytu zwiedzili Kaliningrad. Niektórzy zdecydowali się odwiedzić pobliskie kurorty nadmorskie (m.in. Swietłogorsk oraz Zelenogradzk).

Przed organizacją MŚ 2018 pojawiały się przesłanki, że ceny usług w trakcie trwania mundialu mogą wzrosnąć. Jednakże, w związku z niestabilną sytuacją polityczną oraz sankcjami wobec Rosji w okresie trwania MŚ 2018, odnotowano spadek kursu rubla. W związku z tym ceny usług i towarów były korzystne dla turystów. Ponadto nie zauważono, żeby restauracje i sklepy znacząco podniosły ceny. Jedynie na czas trwania MŚ 2018 odnotowano wzrost cen miejsc noclegowych w hotelach i hostelach. Jak podała „Rzeczpospolita” (2017), „próbująca zamówić nocleg Wiktoria zadzwoniła do 4-gwiazdkowego hotelu w Kaliningradzie, tutaj usłyszała, że można zarezerwować nocleg tylko na cały okres mundialu 14.06-29.06, a najtańszy pokój kosztuje 300 tys. rubli (blisko 19 tys. zł)". Pomimo wysokich cen usług hotelowych zaledwie $1 \%$ respondentów podał, że Kaliningrad jest bardzo drogim miastem. Ceny usług handlowo-turystycznych $49 \%$ badanych oceniło jako średnie. Na niskie ceny wskazało 36\% ankietowanych, byli to głównie mieszkańcy Europy (ryc. 3).

Pomimo wcześniejszych spekulacji o braku doświadczenia lokalnych władz Kaliningradu w organizacji tak dużego wydarzenia, miasto zostało pozytywnie ocenione jako gospodarz MŚ 2018. Znalazło to swoje potwierdzenie w odpowiedziach respondentów. Około 66\% ankietowanych bardzo wysoko oceniło poziom organizacji MŚ 2018. Około $28 \%$ badanych podało, że organizacja mundialu była dobra. Zaledwie $6 \%$ ankietowanych oceniło go negatywnie. Tym samym można wnioskować, że te pozytywne doświadczenia turystów mogą zmniejszyć w przyszłości izolację Obwodu Kaliningradzkiego.

Autorki w swoim opracowaniu zwróciły szczególną uwagę na fakt, czy przyjazd turystów do Kaliningradu na MŚ 2018 wpłynął na ich pozytywną opinię o enklawie i Rosji kontynentalnej. Pozytywne doświadczenia turystów stanowią dla Obwodu Kaliningradzkiego ważny element promocji regionu i rozwoju turystyki. W przeprowadzonym autorskim badaniu ankietowym respondenci zostali zapytani o pierwsze skojarzenie z Rosją. Odpowiedzi udzielone przez ankietowanych dowodzą, że kraj ten jest negatywnie postrzegany przez turystów. Prawie połowa 


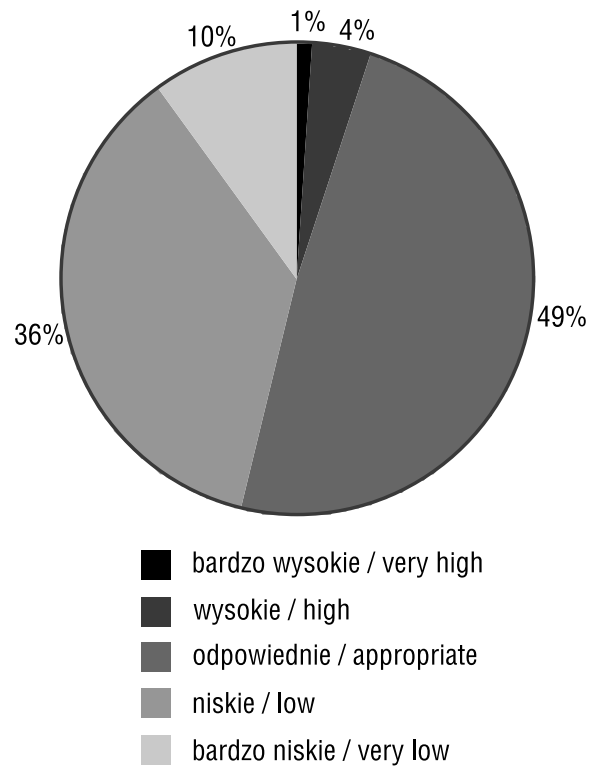

Ryc. 3. Ceny usług handlowo-turystycznych w opinii kibiców MŚ 2018

Fig. 3. Prices of commercial and tourist services in the opinion of the fans of the 2018 World Cup

Źródto: opracowanie własne na podstawie badań ankietowych.

Source: author's own elaboration based on the questionnaire survey. respondentów (48\%) wskazała, że Rosja kojarzy im się z wódką i Władimirem Putinem. Świadczy to o negatywnym i stereotypowym postrzeganiu Rosji. Ponadto znacząca częstość wskazań na prezydenta pozwala twierdzić, że obraz Rosji jest mocno związany z polityką. Odmienne spojrzenie na Rosję wskazali turyści z Azji, dla których Rosja jest tajemniczym i przyjaznym krajem. Biorąc pod uwagę, że wśród badanych byli obywatele Chin, ich wypowiedzi wynikały z bliskich relacji chińsko-rosyjskich. Można wnioskować, że zaznacza się wyraźna różnica w postrzeganiu Rosji przez różne grupy narodowe. Negatywny, stereotypowy wizerunek pojawia się wśród Europejczyków, a pozytywny w opinii Azjatów. Można stwierdzić, że wynika to $\mathrm{z}$ dostępu do różnych informacji i odmiennych relacji UERosja (jednoznacznie negatywnych) i chińsko-rosyjskich (przyjaznych). Pomimo że współczesny obraz Rosji jest zniekształcony wielką polityką, kibice po odwiedzeniu Obwodu Kaliningradzkiego powinni kreować pozytywny wizerunek kraju.

Opinia na temat Rosji najczęściej oparta jest na informacjach podawanych przez krajowe i lokalne media. Większość badanych (75\%), szukając informacji o Rosji przed przyjazdem, korzystała z Internetu. Ankietowani zostali zapytani, czy wizerunek Rosji / Obwodu Kaliningradzkiego przedstawiany w mediach zgadza się z rzeczywistością. Udzielone odpowiedzi podzielono według przynależności terytorialnej, ponieważ przekaz medialny ma inne zabarwienie emocjonalne oraz różną intensywność w zależności od kraju. Odpowiedzi przedstawicieli Europy Środkowo-Wschodniej nie były jednoznaczne. Odpowiednio $1 / 3$ wszystkich badanych nie wie lub nie ma zdania, co do prawdziwości obrazu Rosji przekazywanego przez media, $1 / 3$ uważa, że obraz ten jest raczej prawdziwy i $1 / 3$ że raczej błędny. Prawie 50\% mieszkańców Europy Zachodniej podaje, że wizerunek Rosji przekazywany przez media raczej nie zgadza się z rzeczywistością. Na absolutnie 
nieodpowiedni wizerunek Rosji kreowany w mediach wskazało $24 \%$ badanych. Z kolei $8 \%$ ankietowanych uważa, że obraz Rosji przekazywany przez środki masowego przekazu jest częściowo prawdziwy, a według $4 \%$ badanych zdecydowanie się zgadza z obrazem w środkach masowego przekazu. Do żadnej z powyższych odpowiedzi nie ustosunkowało się $16 \%$ respondentów.

Wykreowany medialny obraz Rosji zniechęca wielu turystów do odwiedzenia tego kraju. Z badania wynika, że $20 \%$ wszystkich Europejczyków miało poważne obawy związane z podróżą do Rosji, głównie z procedurą przekraczania granic. Kibice z Wielkiej Brytanii wskazywali, że przed wyjazdem spotykali się z negatywnymi opiniami o Rosji, wszelkiego rodzaju ostrzeżeniami przed niebezpieczeństwem w trakcie pobytu w enklawie. „Anglicy często jednak podkreślali w krótkich rozmowach, że Kaliningrad jest innym miejscem, niż przedstawiały to brytyjskie media. Te straszyły bowiem kibiców 'miastem-upiorem' oraz określały Kaliningrad jako sowiecko-szare, podupadłe, kryminalne i przemytnicze miasto” („Gazeta Wyborcza” 2018). Większość respondentów nie spotkało się z wrogością mieszkańców enklawy, a ich pobyt przebiegał bezproblemowo. Zaledwie $1 \%$ badanych doświadczyło nieżyczliwości ze strony społeczności lokalnej. Zdecydowana większość respondentów (95\%) pozytywnie oceniła Kaliningrad i jego mieszkańców. Zgodzili się oni, że Rosjanie są bardzo pomocni i życzliwi, a Kaliningrad jest miastem przyjemnym i gościnnym. Oczywiście atmosfera mundialu sprzyjała pozytywnym opiniom. Potwierdza to wypowiedź mieszkańca Kaliningradu „mi też kibice mówią, że jest świetnie (Great!!!)” („Gazeta Wyborcza” 2018). Warto podkreślić fakt, że również lokalne media w Obwodzie Kaliningradzkim przed organizacją MŚ 2018 kreowały negatywny wizerunek kibiców. Przede wszystkim ostrzegano przed kibicami z Anglii oraz zamachami terrorystycznymi. Wydaje się jednak, że kaliningradczycy nie obawiali się kibiców z innych państw, bowiem są otwarci na inne narodowości. Wynika to z ich częstych podróży. Jak podaje Sakson (2014b), zaledwie $18 \%$ mieszkańców enklawy nie było nigdy za granicą.

Organizacja MŚ 2018 umożliwiła wykreowanie nowego wizerunku Rosji na podstawie nie działań i decyzji władz centralnych, ale kontaktu z mieszkańcami. Z badań wynika, że w trakcie mistrzostw bezpośredni kontakt ze społecznością lokalną Kaliningradu miało $88 \%$ badanych. Zdecydowana większość respondentów (83\%) podała, że w trakcie pobytu w enklawie poszerzyła swoją wiedzę o Rosji i Obwodzie Kaliningradzkim. Przeprowadzone badania potwierdzają, że $82 \%$ badanych zmieniło swój stosunek do kraju i jego mieszkańców na pozytywny. W celu dalszego rozwijania sektora turystycznego enklawy niezbędne jest podjęcie szeregu działań. Do najbardziej priorytetowych będą należały:

- rozwój siatki połączeń lotniczych;

- rozwijanie infrastruktury turystycznej;

- liberalizacja reżimu wizowego, np. poprzez wprowadzenie łatwiejszego sposobu nabywania wiz; 
- intensyfikacja współpracy międzynarodowej z innymi miastami europejskimi, celem nabywania doświadczenia w obsłudze rynku turystycznego; istotna będzie także ścisła kooperacja transgraniczna z Gdańskiem, gospodarzem EURO 2012 w celu wymiany doświadczeń z innym miastem-organizatorem na temat podjęcia odpowiedniej strategii po MŚ 2018;

- promocja atrakcyjności turystycznej enklawy (m.in. na oficjalnych stronach internetowych, w mediach społecznościowych), ze szczególnym zwróceniem uwagi na wzrost informacji w języku angielskim; niezmiernie ważne jest również przygotowanie strategii prowadzonej promocji;

- organizacja dużych imprez masowych w celu wykorzystania stadionu wybudowanego na MŚ 2018. Duże eventy powinny być promowane w krajach sąsiadujących, bowiem bliskość Trójmiasta i Wilna pozwala regionowi kaliningradzkiemu na pozyskanie większej liczby potencjalnych klientów.

Działania te wraz z wykreowanym wizerunkiem turystycznym mogą stanowić szansę dla rozwoju turystyki w regionie kaliningradzkim.

\section{Podsumowanie}

Pozytywne oceny organizacji MŚ 2018 i atrakcyjności enklawy, jak również poprawa jakości infrastruktury turystycznej i masowość podróży do Kaliningradu w trakcie mundialu, stworzyły podstawy dla rozwijania turystyki w Obwodzie Kaliningradzkim. Należy stwierdzić, że czerpanie korzyści przez enklawę w dużej mierze zależy od tego, jak władze obwodu wykorzystają istniejący już potencjał i „światowy” wizerunek wykreowany poprzez organizację MŚ 2018.

Przeprowadzone autorskie badania terenowe potwierdziły, że organizacja MŚ 2018 umożliwiła wykreowanie nowego wizerunku Rosji na podstawie nie działań i decyzji władz centralnych, ale kontaktu z mieszkańcami. Jak podali respondenci, słaba promocja Obwodu Kaliningradzkiego i znikome informacje na oficjalnych stronach internetowych enklawy w języku angielskim przyczyniają się do braku wiedzy wśród turystów o tym obwodzie Rosji. Niezbędne jest poszerzenie informacji o Kaliningradzie i zwiększenie aktywności w zakresie marketingu terytorialnego, bowiem doświadczenia kibiców w trakcie MŚ 2018 potwierdzają, że enklawa może stać się atrakcyjnym kierunkiem wakacyjnych podróży, zwłaszcza dla mieszkańców Europy Południowo-Zachodniej, dla których region ten może być „egzotyczną destynacją". Jak zauważa Timothy (1996), enklawy mają unikatowy status destynacji turystycznych. Kaliningrad powinien tę odmienność wykorzystać.

Należy mieć na uwadze, że Obwód Kaliningradzki nie jest autonomiczną jednostką administracyjną i działania jego władz są w dużej mierze uzależnione od decyzji na poziomie centralnym. Niemniej jednak, władze regionu kaliningradzkiego powinny 
podejmować odpowiednie kroki celem zmniejszenia oddziaływania egzogenicznych czynników na funkcjonowanie regionu, tym samym podejmując próbę zmniejszenia wpływu polityki na branżę turystyczną w regionie oraz wizerunek enklawy.

Najbliższe lata będą swoistego rodzaju sprawdzianem. Pozwolą stwierdzić, czy i z jaką siłą zorganizowane MŚ 2018 wpłynęły na zmianę postrzegania atrakcyjności turystycznej enklawy. Przeprowadzenie odpowiednich badań i analiz umożliwi uzyskanie odpowiedzi na pytanie: czy miasto osiągnęło oczekiwany efekt w postaci poprawy wizerunku turystycznego?

\section{Literatura}

Andrades L., Dimanche F., 2017, Destination competitiveness and tourism development in Russia: Issues and challenges, Tourism Management, 62, 360-376.

Borzyszkowski J., 2012, Mistrzostwa Europy w Pitce Nożnej UEFA EURO 2012 a turystyka w Polsce - wstepna ocena, Turystyka Kulturowa, 9, 55-68.

Caiazza R., Audretsch D., 2015, Can a sport mega-event support hosting city's economic, socio-cultural and political development?, Tourism Management Perspectives, 14, 1-2.

Centrum Badania Opinii Społecznej, 2016, Stosunek miesækańców Polski do innych narodów. Komunikat z badań, Warszawa.

Chrabrowo - miediacentr, http://kgd.aero/mediacenter/news/4214895/ (dostęp: 10.10.2018).

Chen F., Tian L., 2015, Comparative study on residents' perceptions of follow-up impacts of the 2008 Olympics, Tourism Management, 51, 263-281.

Domaniewski S., Studzińska D., 2016, The small border traffic zone between Poland and Kaliningrad Region (Russia): The impact of a local visa-free border regime, Geopolitics, 21 (3), 538-555.

Dudek-Mańkowska S., Wawrzyszak A., 2017, Od kryzysu do sukcesu. Metody wyprowadzenia wizerunku destynacji ะ kryzysu, Turystyka Kulturowa, 6, 44-63.

Fourie J., Santana-Gallego M., 2011, The impact of mega-sport events on tourist arrivals, Tourism Management, 32, 1364-1370.

„Gazeta Wyborcza”, 2018, http://trojmiasto.wyborcæa.pl/trojmiasto/7,35612,23614677,kaliningrad-juz-pozegnal-sie-mundialem-zabawa-na-ulicy-do-rana.html (dostęp: 10.10.2018).

Jago L.K., Shaw R.N., 1998, Special events: a conceptual and definitional framework, Festival Management and Event Tourism, 5 (1), 21-32.

Kaliningrad. Pitka Nożna, https://tourism.gov39.ru/news/3889/?sphrase_id=901 (dostęp; 5.10.2018).

Knott B., Fyall A., Jones I., 2015, The nation branding opportunities provided by a sport mega-event: South Africa and the 2010 FIFA World Cup, Journal of Destination Marketing\&Management, 4, 46-56.

Kotowicz W., 2012, Życie polityczne Obwodu Kaliningradzkiego Federacji Rosyjskiej, Wydawnictwo Naukowe Grado, Toruń.

Kowalczyk A., 2005, Nowe formy turystyki miejskiej, Prace i Studia Geograficzne, 35, 155-197. 
Kozak M.W., 2010a, Turystyka: niewykorzystana sæansa rozwojowa regionów?, Studia Regionalne i Lokalne, 4 (42), 43-59.

Kozak M., 2010b, Wielkie imprezy sportowe: korzyšc czy strata?, Studia Regionalne i Lokalne, 1 (39), 48-68.

Kropinova E.G., 2015, Evaluation of tourism development situation in the Russian Federation in 2000-2015: The case of Kaliningrad Region, Mediterranean Journal of Social Sciences, 6 (7), $165-170$.

Lorde T., Greenidge D., Devonish D., 2011, Local residents' perceptions of the ICC Cricket World Cup 2007 on Barbados: Comparisons of pre- and post-games, Tourism Management, 32, 349-356.

Łuczak M., 2010, Kreowanie wizerunku turystycznego Trójmiasta, Zeszyty Naukowe Uniwersytetu Szczecińskiego, 591, 179-189.

Maiello A., Pasquinelli C., 2015, Destruction or construction? A (counter) branding analysis of sport mega-events in Rio de Janeiro, Cities, 48, 116-124.

Malchrowicz-Mośko E., 2015, Pozytywne oraz negatywne implikacje turystyki olimpijskiej, Turystyka Kulturowa, 8, 57-74.

Malchrowicz-Mośko E., Kamel M., Poczta J., 2016, Wpływ wydaræeń sportowych na wizerunek miasta na przyktadzie Poznania, Journal of Education, Health and Sport, 6 (4), 211-232.

Marczak M., 2014, Wptyw organizacji wielkich eventów pitkarskich na rozwój turystyki na przykładzie wybranych destynacji, Turystyka Kulturowa, 12, 54-67.

Palmowski T., 2013, Kaliningrad - szansa czy sagrożenie dla Europy Battyckiej? Monografia spoteczno-gospodarcza, Wydawnictwo Bernardinum, Gdańsk - Pelplin.

Pappas N., 2014, Hosting mega events: Londoners' support of the 2012 Olympics, Journal of Hospitality and Tourism Management, 21, 10-17.

Potocka I., 2009, Atrakcyjnoš́ turystyczna i metody jej identyfikacji [w:] Z. Młynarczyk, A. Zajadacz (red.), Uwarunkowania i plany rowwoju turystyki. Walory i atrakcje turystyczne. Potencjat turystyczny. Plany rozwoju turystyki, t. III, Wydawnictwo Naukowe Uniwersytetu im. Adama Mickiewicza w Poznaniu, Poznań, 19-32.

Rapacz A., Jaremen D., 2011, Atrakcyjność turystyczna jako czynnik wyboru destynacji turystycznej, Zeszyty Naukowe Uniwersytetu Szczecińskiego, 663, 131-141.

Raport: popularności Rosji wśród zagranicznych turystów, https://tourism.interfax.ru/ru/news/ articles/52778/ (dostęp: 2.10.2018).

Roche M., 2006, Part I sports mega-events, modernity and capitalist economies: Mega-events and modernity revisited: globalization and the case of the Olympics, The Sociological Review, 54, 25-40.

Rogoża J., Wierzbowska-Miazga A., Wiśniewska I., 2012, Wyspa na uwięzi. Kaliningrad między Moskwq a UE. Prace OSW, Ośrodek Studiów Wschodnich im. Marka Karpia, Warszawa. Rosstat, 2016, Russia in figures 2016. Statistical handbook, Moscow.

„Rzeczpospolita”, https://www.rp.pl/Finanse/310299981-Rosyjski-mundial-astronomiczneceny-hoteli-w-Kaliningradzie.html (dostęp: 29.10.2017). 
Sakson A., 2014a, Obwód Kaliningradzki a bezpieczeństwo Polski, Przegląd Strategiczny, 7, 109-121.

Sakson A., 2014b, Socjologia pogranicæa spoteczności postmigracyjnych Ziem Zachodnich i Pótnocnych Polski. Kilka uwag o jej uprawianiu [w:] M. Zielińska, B. Trzop (red.), Transgraniczność w perspektywie socjologicznej. Pogranicza i centra wspótczesnej Europy, Lubuskie Towarzystwo Naukowe, Zielona Góra, 149-155.

Stasiak A., 2016, Doświadczenie - stary-nowy paradygmat turystyki, Folia Turistica, 41, 191-216.

Statista, https://www.statista.com/statistics/888119/russia-international-tourist-arrivals/ (dostęp: 8.10.2018).

Timothy D. J., 1996, Small and isolated: the politics of tourism in international exclaves, Acta Turistica, 8 (2), 99-115

Toman T., Borzyszkowski J., 2012, Wpływ Mistrzostw Europy w Pitce Nożnej EURO 2012 na rynek turystyczny Trójmiasta w opinii mieszkańców aglomeracji, Turystyka Kulturowa, 3, 16-28.

Turystyka w Rosji, www.turstat.com (dostęp: 1.10.2018).

Wenerski Ł., 2014, Maty ruch granicæny pisany cyrylica, Instytut Spraw Publicznych, Warszawa. Wiśniewska I., Domańska M., Strzelecki J., Żochowski P., Wilk A., Menkiszak M., 2016, Obwód Kaliningradzki 2016: spoteczeństwo, gospodarka, armia. Raport OSW, Ośrodek Studiów Wschodnich im. Marka Karpia, Warszawa.

Zhou Y., Ap J., 2009, Residents' perceptions towards the impact of the Beijing 2008 Olympic Games, Journal of Travel Research, 48, 78-91.

\author{
Julia Dunaj \\ Uniwersytet im. Adama Mickiewicza w Poznaniu \\ Wydziat Nauk Spotecznych \\ Zaktad Metod i Technik Badań Socjologicznych \\ ul. Szamaræewskiego 89, 60-568 Poznań \\ socjolog@amu.edu.pl \\ Dominika Studzinska \\ Uniwersytet Gdański \\ Wydziat Oceanografii i Geografii \\ Katedra Geografii Spoteczno-Ekonomicznej \\ ul. Ba:̇yńskiego 4, 80-309 Gdańsk \\ geods@univ.gda.pl
}

